\title{
Cholestatic Jaundice as a Manifestation of Multisystem Inflammatory Syndrome in Children (MIS-C)
}

\author{
Kishore Kumar Narahari ${ }^{1} \cdot$ Rajeev Pothala $^{1} \cdot$ Sushma Poornima Bathina ${ }^{1} \cdot$ Namita Deshmukh $^{1} \cdot$ Chanchal Kumar $^{1}$ (D)
}

Received: 29 April 2021 / Accepted: 15 June 2021 / Published online: 28 July 2021

(c) Dr. K C Chaudhuri Foundation 2021

To the Editor: A 2-y-old male child presented with 1 wk of high colored urine and pale stool alone followed by high grade fever, erythematous maculopapular rash, and loose stools for 3 d. He was managed appropriately for severe dehydration with hypotensive shock. The clinical possibilities considered were acute viral hepatitis, bacterial infection, toxic shock syndrome, Kawasaki disease, and COVID infection. The initial investigations were as follows: total leukocyte count $-3770 / \mathrm{mm}^{3}$, neutrophils - $48 \%$, lymphocytes - $48 \%$, normal platelet count, total bilirubin - $6.3 \mathrm{mg} / \mathrm{dL}$, direct bilirubin $-4.3 \mathrm{mg} / \mathrm{dL}$, serum glutamic-oxaloacetic transaminase (SGOT) - $70 \mathrm{IU} /$ $\mathrm{mL}$, serum glutamic-pyruvic transaminase (SGPT) - $96 \mathrm{IU} /$ $\mathrm{mL}, \mathrm{C}$-reactive protein $(\mathrm{CRP})-76 \mathrm{mg} / \mathrm{L}$, procalcitonin$1.54 \mathrm{ng} / \mathrm{mL}$, RT-PCR for SARS-CoV-2 - negative, anti-HAV and anti-HEV IgM - negative, HBsAg - negative, HCV negative, blood culture and urine culture - no growth. He continued to have high grade fever, developed limb edema and redness of lips, deepening of jaundice (total bilirubin $8.3 \mathrm{mg} / \mathrm{dL}$, direct bilirubin $-4.3 \mathrm{mg} / \mathrm{dL}$, SGOT - $56 \mathrm{IU} /$ $\mathrm{mL}$, SGPT - $67 \mathrm{IU} / \mathrm{mL}$ ), elevated inflammatory markers (CRP - $74 \mathrm{mg} / \mathrm{L}$ and procalcitonin - $1.24 \mathrm{ng} / \mathrm{mL}$ ). Multisystem inflammatory syndrome in children (MIS-C) was considered and COVID IgG antibody titer was elevated (11.33). He fulfilled the criteria for MIS-C; tier-2 investigations showed the following: D-dimer $-897 \mathrm{ng} / \mathrm{mL}$, ferritin $-365 \mathrm{ng} / \mathrm{mL}$, INR-1.0, troponin level-normal and echocardiographynormal [1]. He was initiated on methylprednisolone (1-2 mg/ $\mathrm{kg} / \mathrm{d}$ ) and intravenous immunoglobulin (IVIG) at $2 \mathrm{~g} / \mathrm{kg}$ to which he responded and became afebrile in next $24 \mathrm{~h}$; total bilirubin reduced to $3 \mathrm{mg} / \mathrm{dL}$ (direct bilirubin $-1.5 \mathrm{mg} / \mathrm{dL}$ ). He was discharged on oral prednisolone and aspirin. Many cases of atypical Kawasaki-like illness or MIS-C have been reported in older children [2]. Fever and gastrointestinal symptoms are the primary manifestations of MIS-C [3]. Acute hepatitis as a manifestation of MIS-C is associated with higher rates of shock, requirement of respiratory support, and longer hospitalization times [4]. This case highlights the rare presentation of MIS-C with cholestatic jaundice at onset followed by gastrointestinal involvement.

\section{Declarations}

Conflict of Interest None.

\section{References}

1. World Health Organization. Multisystem inflammatory syndrome in children and adolescents with COVID-19. In: Scientific brief: World Health Organization. 2020. Available at: https://who. int/publications-detail/multisysteminflammatory-syndrome-inchildren-andadolescents-with-covid-19. Accessed on 10 March 2021.

2. Verdoni L, Mazza A, Gervasoni A, et al. An outbreak of severe Kawasaki-like disease at the Italian epicentre of the SARS-CoV-2 epidemic: an observational cohort study. Lancet. 2020;395:1771-8.

3. Tang Y, Li W, Baskota M, et al. Multisystem inflammatory syndrome in children during the coronavirus disease 2019 (COVID19) pandemic: a systematic review of published case studies. Transl Pediatr. 2021;10:121-35.

4. Cantor A, Miller J, Zachariah P, DaSilva B, Margolis K, Martinez M. Acute hepatitis is a prominent presentation of the multisystem inflammatory syndrome in children: asingle-centerreport. Hepatology. 2020;72:1522-7.

Publisher's Note Springer Nature remains neutral with regard to jurisdictional claims in published maps and institutional affiliations.

Chanchal Kumar

drchanchalkumarkem@gmail.com

1 Department of Pediatrics, Ankura Hospital for Women and Children, Hyderabad, Telangana 500039, India 